Original Article

\title{
HEPATOPROTECTIVE EFFECT OF N-MIRACLE (POLYHERBAL FORMULATION) AGAINST ETHANOL INDUCED TOXICITY IN MALE ALBINO RATS
}

\author{
MEENATCHI SUNDARAM ANGAPPAN \\ Department of Clinical Laboratory, National Homoeopathy Research Institute in Mental Health (Under Central Council for Research in \\ Homoeopathy (Ccrh), Ministry of Ayush Govt of India), Sachivothamapuram Post, Kottayam 686532, Kerala, India \\ Email: spmangappan@gmail.com
}

Received: 30 Mar 2020, Revised and Accepted: 30 Apr 2020

ABSTRACT

Objective: The aim of this current study is to investigate the hepatoprotective efficacy of N-Miracle (a polyherbal formulation) against ethanolinduced toxicity in male albino rats.

Methods: Male Wistar albino rats weighing 150-200 g were used for the study. A total of 30 male albino rats were selected, divided into five groups. Ethanol-induced liver damage was done on Group III, IV, and V. Group I and Group II served as a normal and drug (N-Miracle) control. After the treatment period, the rats were anaesthetized by light ether anesthesia in a lethal chamber. Hepatic biomarkers, antioxidant enzymes, histopathological examination are carried out to document the hepatoprotective effect of N-Miracle (Polyherbal formulation).

Results: The results of the present study demonstrated a significant $(\mathrm{p}<0.05)$ increase in the levels of Aspartate Aminotransaminase (AST), Alanine Aminotransaminase (ALT) and Alkaline Phosphatase (ALP) in ethanol-induced rats as compared to normal and drug control Groups. The level of total protein and albumin were significantly $(\mathrm{p}<0.05)$ decreased in ethanol-treated rats. The toxic impact of ethanol was found to be restored in rats treated with N-Miracle (Polyherbal formulation). The present study also exhibited the enzymatic antioxidant efficacy of N-Miracle (Polyherbal formulation) against ethanol-induced toxicity in rats by increasing the antioxidant enzymes such as superoxide dismutase, catalase, glutathione peroxidase and decreasing the activity of Glutathione-S-transferase in the liver. The findings are also correlated with histopathological examination of N-Miracle treated group, which shows hepatic regeneration and decrease in degradation of hepatocytes.

Conclusion: This study could provide a possible explanation to hepatotoxicity resulting from exposure to ethanol. The findings of the present study revealed the ameliorative effect of N-Miracle (Polyherbal formulation) against ethanol-induced hepatotoxicity by improving the liver function, increasing the levels of antioxidant enzymes and restoring the morphological features of the liver.

Keywords: Ethanol, Polyherbal formulation, N-Miracle, Hepatotoxicity, Antioxidant etc

(C) 2020 The Authors. Published by Innovare Academic Sciences Pvt Ltd. This is an open access article under the CC BY license (http://creativecommons.org/licenses/by/4.0/) DOI: http://dx.doi.org/10.22159/ijpps.2020v12i12.39672. Journal homepage: https://innovareacademics.in/journals/index.php/ijpps.

\section{INTRODUCTION}

The liver is the chief vital organ and the site for necessary biochemical reactions in the human system. The core function of the liver is to purify toxic substances and to synthesize useful biochemical compounds. Hepatotoxicity may result from direct toxicity of the primary compound and/or from a reactive metabolite or from an immunologically-mediated response affecting hepatocytes, biliary epithelial cells and/or liver vasculature[1] Ethanol toxicity was discovered to be a major cause of liver disorder for centuries. It is a growing medical and public health issue challenged by the adult and adolescent populations. Advancement to an alcoholic liver disease is a multifactorial process that includes a number of genetic, nutritional and environmental causes [2]. The liver cells are chiefly susceptible to alcohol-related injury such as fatty liver, hepatitis, and cirrhosis because it is the primary site of alcohol metabolism. Alcohol-induced hepatotoxicity has been perceived to develop largely through the extreme generation of free radicals and reactive oxygen species as well as an impaired antioxidant defense mechanism, which results in oxidative stress with associated health problems [3]. Near about $80-90 \%$ of alcohol is metabolized in the liver, where alcohol is oxidized to acetaldehyde. The metabolic process is catalysed by different enzymes like alcohol dehydrogenase $(\mathrm{ADH})$, microsomal ethanol metabolizing system and acetaldehyde dehydrogenase. Acetaldehyde metabolic product of alcohol is more lethal than alcohol and it is connected with a more number of the metabolic disorders in liver disease triggered by alcohol. Alcohol ingestions have been found to cause the build-up of reactive oxygen species, which is the basis of lipid peroxidation of cellular membranes and proteins as well as DNA oxidation, resulting in liver cell necrosis [4]. In spite of the advancement in allopathic system of medicine, effective allopathic medicines are higher cost as well as associated with several adverse effects. Herbal remedies are proven to play a vital role in the treatment of liver diseases [5].

Plants have a great ability for producing new drugs for human benefit According world health organization, more than $80 \%$ of world's populations depend on the traditional remedy for their basic healthcare needs [6]. In Ayurveda, single or multiple herbs (polyherbal) are used for the treatment. The idea of polyherbalism is to attain superior therapeutic effectiveness. The active phytochemical ingredients of distinct plants are insufficient to achieve the appropriate therapeutic effects. When combining the multiple herbs in a particular ratio, it will give a better therapeutic efficacy. Besides, polyherbal formulations bring to improved convenience for patients by excluding the need of taking more than one different single herbal preparation at a time, which indirectly leads to better compliance and therapeutic effect. All these benefits have resulted in the recognition of polyherbal formulation in the market when compared to single herbal formulation [7].

N-Miracle, a polyherbal formulation, was prepared by the combination of Conium maculatum L, Lycopodium Clavatum, Selenium, Vitex agnus castus L, Pausinystalia yohimbe, Caladium seguinum. These medicinal plants have diversified pharmacological effect; however, the hepatoprotective effect of the combination of the above plants are not yet carried out.

\section{MATERIALS AND METHODS}

\section{Drugs and chemicals}

N-Miracle (Polyherbal formulation) was provided by Dr. Ramesh Shankar, Sai Brindavan Homeo Clinic, Omalur Main Road, Salem, 
Tamil Nadu, India 636455 as a gift sample and it was used to carry out the current research work. All other chemicals and reagents used in the present study were obtained commercially and were of analytical grade.

\section{Experimental animals}

Male Wistar albino rats weighing 150-200 g were obtained from TamilNadu Veterinary and Animal Sciences University, Chennai and used for the study. The animals were fed with commercial pellet feed obtained from Sai Durga Foods and Feeds, Bangalore, India and water ad libitum. The animals were subjected to $12 \mathrm{~h}$ light/dark cycle under standard laboratory conditions at a temperature of 24$28{ }^{\circ} \mathrm{C}$ with a relative humidity of $60 \%-70 \%$. The animal experiments were carried out as per the guidelines of Animal Ethical Committee (CPS/IAEC/AH/P/19/20).

\section{Experimental design}

After one week of acclimatization period, male albino rats were divided randomly into five groups of six animals each.

Group I: Normal control rats were treated with oral dose of distilled water for $30 \mathrm{~d}$.

Group II: Rats were treated with N-Miracle (Polyherbal formulation) $20 \mathrm{mg} / \mathrm{kg}$ body weight/day for $30 \mathrm{~d}$.

Group III: Rats were treated with ethanol 20\%v/v, $1.6 \mathrm{~g} / \mathrm{kg}$ body weight/day for $30 \mathrm{~d}$.

Group IV: Rats were treated with ethanol as given in Group III for 15 d. After ethanol induction for $15 \mathrm{~d}$, N-Miracle (Polyherbal formulation) was given as given in Group II for the next $15 \mathrm{~d}$.

Group: V: Animals were treated with ethanol as given in Group III and N-Miracle (Polyherbal formulation) as given in Group II simultaneously for $30 \mathrm{~d}$.

\section{Blood samples}

After the treatment period, the rats were anaesthetized by light ether anaesthesia in lethal chamber. Blood samples were collected through a direct intracardiac puncture from each rat. Blood was collected in a dry test tube and allowed to coagulate at ambient temperature for $45 \mathrm{~min}$. Serum was separated by centrifugation at $3500 \mathrm{rpm}$ for $10 \mathrm{~min}$ and stored at $-20{ }^{\circ} \mathrm{C}$ for biochemical analysis.

\section{Tissue homogenate preparation}

A vertical midline thoracic and abdominal incision was done to explore the viscera. Liver of each animal was excised, cleaned from their surrounding fat and connective tissue, washed with normal saline, blotted with filter paper and rinsed in ice-cold saline. Half of each organ was homogenized for enzymatic analysis and the other half of organ was stored in $10 \%$ formalin for histological examination. The collected liver tissue of different experimental groups was homogenized in Tris- $\mathrm{HCl}$ buffer $(0.1 \mathrm{M}, \mathrm{pH} 7.4)$ using a Teflon homogenizer at $4{ }^{\circ} \mathrm{C}$; the crude tissue homogenate was then centrifuged at a speed of $9000 \mathrm{rpm}$ for $15 \mathrm{~min}$ in cold centrifuge, the supernatant was kept at-20 ${ }^{\circ} \mathrm{C}$ for assay of enzymatic antioxidant analysis [8].

\section{Tissue samples for histopathological examination}

The liver tissue was dissected out and washed in saline, cut into pieces of desired size and fixed in Bouin-Hollande fixative for $24 \mathrm{~h}$. After removal of excess picric acid and dehydrated in graded series of alcohol, the tissues were infiltrated with molten paraffin at 58-60 ${ }^{\circ} \mathbf{C}$ and finally embedded in paraffin, 3-5 micron thick sections of all the tissues were obtained using a rotary microtome (Weswox, India) and stained in haematoxylin and eosin as counter stain. The slides were mounted using DPX mountant and examined at $400 \mathrm{x}$ magnification using photographic microscope [8].

\section{Biochemical and enzymatic antioxidant analysis}

Total protein and albumin in the serum were estimated by Biuret method [9]. Serum Aspartate Aminotranasminase (AST) and Alanine Aminotransaminase (ALT) were assayed by using the diagnostic kit based on the colorimetric method [10]. Serum alkaline phosphatase was estimated by using the diagnostic kit based on colorimetric method [11]. The activities of superoxide dismutase, catalase, glutathione peroxidase, and glutathione-S-transferase were assayed by using standard colorimetric method [12-15].

\section{Statistical analysis}

The results were expressed as the mean value \pm SD. Group comparisons were performed by using one-way analysis of variance (ANOVA) test. Significant difference between normal control and experimental groups were assessed by student's t-test. A probability level of less than $5 \%(\mathrm{P}<0.05)$ was considered as significant [16].

\section{RESULTS AND DISCUSSION}

\section{Biochemical analysis}

There was a decrease in total protein and albumin in ethanol-treated animals (Group III) as compared to control rats (Group I). We also found that there was significant $(\mathrm{p}<0.05)$ increase in total protein in $\mathrm{N}$-Miracle (Polyherbal formulation) (Group IV) compared to ethanol treated rats (Group III). Simultaneous treatment with ethanol and NMiracle (Polyherbal formulation) shows a considerable increase in total protein as compared to ethanol alone treated rats, which indicates the combined effect of N-Miracle (Polyherbal formulation). We found that there was a significant $(\mathrm{p}<0.05)$ increase in Aspartate Aminotransaminase (AST), Alanine Aminotransaminase (ALT) and Alkaline Phosphatase (ALP) in ethanol-induced animals (Group III) as compared to normal control rats (Group I). We also found that there was considerable $(\mathrm{p}<0.05)$ decrease in Aspartate Aminotransaminase (AST), Alanine Aminotransaminase (ALT) and Alkaline Phosphatase (ALP) in N-Miracle treated animals (Group IV) compared to ethanol-induced group (Group III). In Group V, there was a significant $(\mathrm{p}<0.05)$ decrease in Aspartate Aminotransaminase (AST), Alanine Aminotransaminase (ALT) and Alkaline Phosphatase (ALP) as compared to ethanol-treated rats, which indicates the efficacy of N-Miracle (Polyherbal formulation).

Table 1: Effect of N-miracle (a polyherbal formulation) on serum total protein, albumin, Aspartate aminotransaminase (AST), Alanine aminotransaminase (ALT) and Alkaline Phosphatase (ALP) in different experimental groups of rats

\begin{tabular}{|c|c|c|c|c|c|}
\hline Groups & Total protein (g/dl) & Albumin (g/dl) & AST (U/l) & ALT (U/l) & ALP (U/l) \\
\hline $\mathrm{I}$ & $8.95 \pm 0.32^{\mathrm{a}}$ & $2.1 \pm 0.02^{\mathrm{a}}$ & $12.20 \pm 1.50^{\mathrm{a}}$ & $26.29 \pm 2.0^{\mathrm{a}}$ & $188 \pm 10.80^{a}$ \\
\hline II & $9.10 \pm 0.23^{a}$ & $1.98 \pm 0.03^{\mathrm{a}}$ & $12.00 \pm 3.20^{\mathrm{a}}$ & $25.89 \pm 3.1^{\mathrm{a}}$ & $184.8 \pm 11.40^{\mathrm{a}}$ \\
\hline III & $7.0 \pm 0.25^{b}$ & $1.95 \pm 0.03^{b}$ & $19.90 \pm 2.28^{\mathrm{b}}$ & $39.29 \pm 3.3^{b}$ & $278.8 \pm 11.90^{b}$ \\
\hline IV & $8.88 \pm 0.45^{\mathrm{a}}$ & $2.0 \pm 0.03^{\mathrm{a}}$ & $13.10 \pm 2.50^{\mathrm{a}}$ & $33.69 \pm 2.9^{a}$ & $232.5 \pm 11.50^{a}$ \\
\hline $\mathrm{V}$ & $8.01 \pm 0.48^{\mathrm{a}}$ & $2.02 \pm 0.21^{\mathrm{a}}$ & $11.39 \pm 2.74^{\mathrm{a}}$ & $31.11 \pm 2.17^{\mathrm{a}}$ & $194.2 \pm 5.18^{\mathrm{a}}$ \\
\hline
\end{tabular}

Values were means of \pm SD of six rats, values not sharing a common superscript differ significantly at $\mathrm{P}<0.05$

Hepatic cells take part in a variety of metabolic actions and control a host of enzymes. During liver injury, transport function of the hepatocytes was interrupted which leads to leakage of plasma membrane, thereby causing an increased enzyme level in serum [17]. In the current study, we observed a significant increase in the activities of liver marker enzymes such as Aspartate Aminotransaminase (AST), Alanine
Aminotransaminase (ALT) and Alkaline Phosphatase (ALP) on ethanol intoxicated rats, which indicates increased permeability, damage and/or necrosis of hepatocytes [18]. Treatment with N-Miracle (Polyherbal formulation) significantly alleviated the activities of liver marker enzymes to normal levels, which might be a consequence of stabilization of plasma membrane and maintaining the functional status of the liver 
from ethanol toxicity. The current study was supported by Margaret and Jayshree (2014) who have revealed Vitex agnus castus L. (one of the herb present in our polyherbal formulation N-Miracle) was useful in hepatic disorders. Phytochemical studies showed the presence of flavonoids, glycosides, and alkaloids, which contribute to hepatoprotective activity. Hence from this study we concluded that Vitex agnus castus $\mathrm{L}$, the active constituent of our polyherbal formulation N-Miracle was rich in several phytoconstituents, which showed good hepatoprotective activity, this was comparable with the hepatic enzymes [19].

\section{Enzymatic antioxidant analysis}

In rats treated with ethanol (Group III), there was a significant $(\mathrm{p}<0.05)$ decrease in Superoxide dismutase (SOD), Catalase (CAT), Glutathione Peroxidase (GPx) levels as compared to control animals
(Group I). There was a significant $(\mathrm{p}<0.05)$ increase in SOD, CAT, and GPx levels in N-Miracle treated animals (Group IV). During combined treatment of ethanol and N-Miracle (Polyherbal formulation) (Group $\mathrm{V})$, there was a considerable $(\mathrm{p}<0.05)$ increase in Superoxide dismutase (SOD), Catalase (CAT), and Glutathione Peroxidase (GPx) levels as compared to ethanol-treated rats, which indicated the combined effect of $\mathrm{N}$-Miracle (Polyherbal formulation). We also found that there was significant $(\$ 0.05)$ increase in Glutathione Stransferase (GST) levels in Group III as compared to Group I. The significant ( $\mathrm{k}<0.05)$ decreases in Glutathione S-transferase (GST) levels in Group IV were also noted. In Group V, there were a significant ( $\beta \times 0.05)$ decrease in Glutathione S-transferase (GST) levels as compared to ethanol-treated rats, which indicated the combined effect of N-Miracle (Polyherbal formulation).

Table 2: Effect of N-miracle (Polyherbal formulation) on enzymatic antioxidant in Liver tissue in different experimental groups of rats

\begin{tabular}{|c|c|c|c|c|}
\hline Groups & $\begin{array}{l}\text { SOD }(\mathrm{U} / \mathrm{min} / \mathrm{mg} \text { of } \\
\text { protein) }\end{array}$ & $\begin{array}{l}\text { CAT } \\
(\mu \mathrm{mol} / \mathrm{min} / \mathrm{mg} \text { of protein })\end{array}$ & $\begin{array}{l}\text { GPx } \\
(\mu \mathrm{mol} / \mathrm{min} / \mathrm{mg} \text { of protein })\end{array}$ & $\begin{array}{l}\text { GST } \\
(\mu \mathrm{mol} / \mathrm{min} / \mathrm{mg} \text { protein })\end{array}$ \\
\hline I & $9.45 \pm 0.75^{\mathrm{a}}$ & $75.75 \pm 4.89^{a}$ & $11.28 \pm 1.10^{\mathrm{a}}$ & $3.13 \pm 0.43^{\mathrm{a}}$ \\
\hline II & $9.25 \pm 0.60^{\mathrm{a}}$ & $76.86 \pm 5.25^{a}$ & $10.80 \pm 0.90^{\mathrm{a}}$ & $3.28 \pm 0.43^{a}$ \\
\hline III & $4.30 \pm 0.44^{b}$ & $45.10 \pm 3.90^{\mathrm{b}}$ & $4.29 \pm 0.19 \mathrm{~b}$ & $6.36 \pm 0.20^{b}$ \\
\hline IV & $8.90 \pm 0.45^{\mathrm{a}}$ & $73.90 \pm 4.15^{\mathrm{a}}$ & $10.78 \pm 0.80^{\mathrm{a}}$ & $3.90 \pm 0.35^{\mathrm{a}}$ \\
\hline V & $9.18 \pm 0.86^{\mathrm{a}}$ & $72.49 \pm 6.35^{\mathrm{a}}$ & $11.10 \pm 0.12^{\mathrm{a}}$ & $4.10 \pm 0.2^{\mathrm{a}}$ \\
\hline
\end{tabular}

Values were mean \pm SD of six rats, values not sharing a common superscript differ significantly at $\mathrm{P}<0.05$

Free radical generation inhibition is important in protection against ethanol-induced hepatic lesion. This is accomplished by a set of endogenous antioxidant enzymes such as Superoxide dismutase (SOD), Catalase (CAT) and Glutathione S-transferase (GST) [20]. Reduction in endogenous antioxidant was obviously connected with ethanol-induced oxidative stress, which was characterized by the generation of toxic acetaldehyde and other reactive molecules in the cell. The obtained result agrees with the findings of Hussain et al., (2001) and Molina et al., (2002) who reported that chronic ethanol treatment caused a significant reduction in hepatic antioxidant enzymes level [21-22]. In the present study, ethanol treatment induced a significant decrease in Superoxide dismutase (SOD), Catalase (CAT), Glutathione peroxidise (GPx) activities in the liver of rats when compared to the control group. These changes were markedly reversed by treatment with N-Miracle (Polyherbal formulation). The reduction in the activities of these antioxidant enzymes might be due to the inhibition of their synthesis by some reactive molecules produced during ethanol metabolism. It could also be as a result of oxidation of the enzymatic proteins by the generated reactive oxygen species. Glutathione-S-transferase (GST) was a very important enzyme that plays an important role in the detoxification and metabolism of many foreign and endobiotic compounds [23].

Increase in Glutathione-S-transferase (GST) activity was likely a protective response to purify the toxic metabolites generated in the

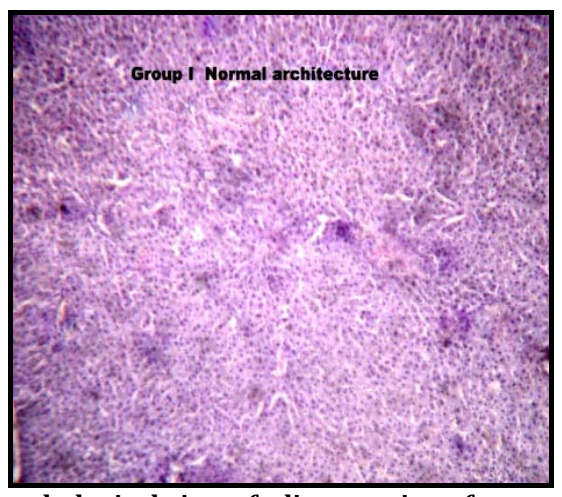

Histopathological view of a liver section of group I rats course of ethanol metabolism. When compared with rats treated with ethanol alone, co-treatment of rats with N-Miracle (Polyherbal formulation) and ethanol significantly reduced the hepatic Glutathione-S-transferase (GST) activity. The reduction in the hepatic Glutathione-S-transferase (GST) activity might be attributed to the antioxidant properties associated with the phenolic and flavonoid compound in N-Miracle (Polyherbal formulation), which enabled it to protect the liver against the dilapidating effect of ethanol [24]. The positive alteration of enzymatic antioxidant in liver tissue might be due to the presence of Lycopodium clavatum (one of herb present in the polyherbal formulation).

\section{Histopathology of liver}

The liver of the control group (Group I) rats showed normal histological architecture. Histoarchitectural examination of the liver sections of rats treated with ethanol (Group III) showed hepatocellular lesions such as hydropic degeneration, microvesicular steatosis and vacuolization compared with the control group (Group I). The rats treated with $20 \mathrm{mg} / \mathrm{kg}$ of N-Miracle (Polyherbal formulation) (Group IV) showed improved histological architecture. The rats treated with $20 \mathrm{mg} / \mathrm{kg}$ body weight of $\mathrm{N}$ Miracle (Polyherbal formulation) post and co-treatment (Group V) showed signs of protection against ethanol to a considerable extent as evident from the formation of normal hepatic regeneration and decrease in degeneration and vacuoles in the liver histology.

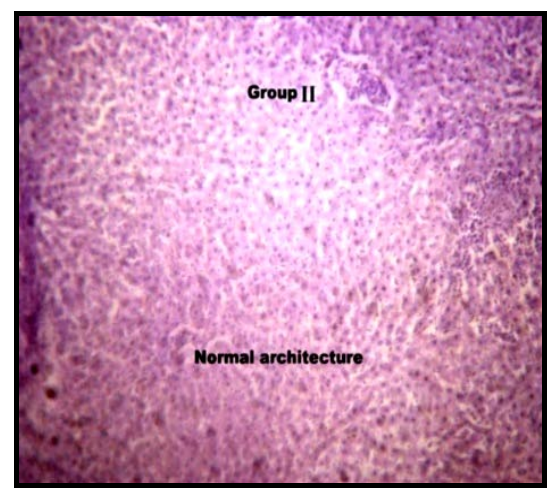

Histopathological view of liver section of group II rats 


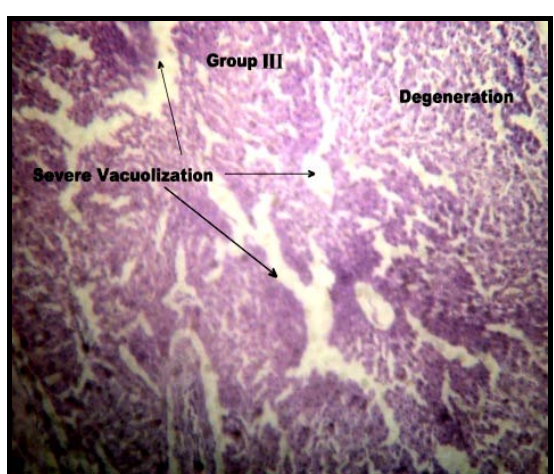

Histopathological view of liver Section of Group III rats

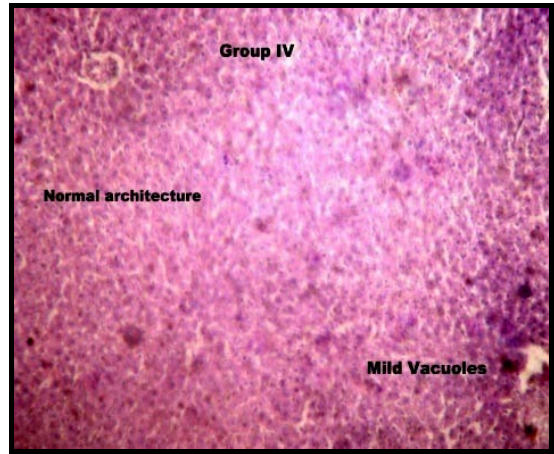

Histopathological view of liver Section of Group IV rats

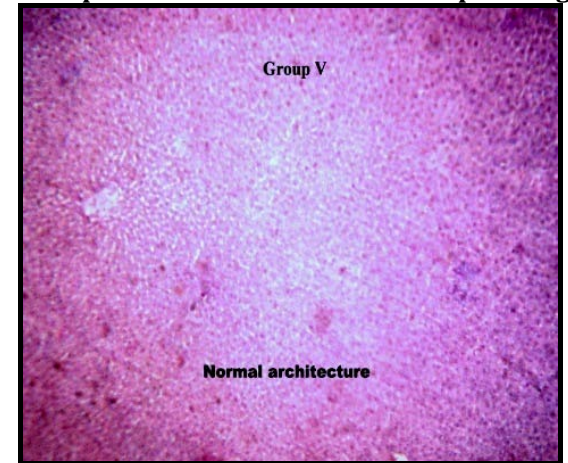

Histopathological view of liver section of group $\mathrm{V}$ rats

Fig. 1: Effect of N-Miracle (Polyherbal formulation) on histopathological changes in liver section

\section{CONCLUSION}

The findings of the present study revealed the ameliorative effect of N-Miracle (Polyherbal formulation) against ethanol-induced hepatotoxicity by improving the liver function, increasing the levels of enzymatic antioxidants such as superoxide dismutase, catalase, glutathione peroxidase and decreasing the activity of Glutathione-Stransferase (GST) in the liver and also restoring morphological features of liver. Thus, N-Miracle (Polyherbal formulation) can be used for hepatoprotective treatment. Further study is required to demonstrate the hepatoprotective efficacy of N-Miracle.

\section{FUNDING}

Nil

\section{AUTHORS CONTRIBUTIONS}

Both authors have contributed equally.

\section{CONFLICT OF INTERESTS}

There are no conflicts of interest.

\section{REFERENCES}

1. Panda Amaresh, Rath Seemanchala, Pradhan Debashis, Mahanty Arpan, Gupta Bijan Kumar, Bala Nripendra Nath. Hepatoprotective activity of the whole part of the plant Cuscuta reflexa roxb. (Convolvulaceae) in chloroform, ethanol and paracetamol-induced hepatotoxic rat models. Int J Pharm Clin Res 2014;6:127-32.

2. Arulmozhi V, Krishnaveni M, Mirunalini S. Protective effect of Solanum nigrum fruit extract on the functional status of liver and kidney against ethanol-induced toxicity. J Biochem Tech 2012;3:339-43.

3. Wu D, Cederbaum AI. Alcohol oxidative stress and free radical damage. Alcohol Res Health 2003;27:277-84.

4. Tarasankar M, Ayaz A, Nilanjan P. Evaluation of hepatotherapeutic effects of Mikania scandens (L.) willd on alcohol-induced hepatotoxicity in rats. Int J Pharm Pharm Sci 2012;3:490-4.

5. Said O, Khalil K, Fulder S. Ethnobotanical survey of medicinal herbs of the middle Eastern region. J Ethnopharmacol 2002;83:251-65.
6. Duraipandiyan V, Ayyanar M, Ignacimuthu S. Antimicrobial activity of some ethnomedicinal plants used by Paliyar tribe from Tamil Nadu, India. BMC Comp Alt Med 2006;6:35-41.

7. Dhanaraj SK, Parasuraman S, Thing GS. Polyherbal formulation: concept of ayurveda. Pharmacogn Rev 2014;8:73-80.

8. Ochei J, Kolhatkar A. Medical laboratory science, theory and practice, New Delhi tata mcgraw hill publishing company limited; 2000. p. 276-7.

9. Reinhold JG, Reiner M. Manual determination of serum total protein, albumin, and globulin fractions by biuret method. Standard Method Clin Chem Academic Press New York; 1953. p. 88.

10. Reitman S, Frankel S. Glutamic-pyruvate transaminase assay by colorimetric method. Am J Clin Path 1957;28:56.

11. Kind PRN, King EJ. Estimation of plasma phosphatase by determination of hydrolyzed phenol with antipyrene. J Clin Pathol 1954;7:322.

12. Kakkar P, Das B, Viswanathan PN. A modified spectrophotometric assay of superoxide dismutase. Ind J Biochem Biophys 1984;21:130-32.

13. Sinha KA. Colorimetric assay of catalase. Anal Biochem 1972;47:389-94.

14. Rotruck JT, Pope AL, Ganther HE, Swanson AB, Hafeman DG, Hoekstra WG. Science 1973;179:588-90.

15. Habig WH, Pabst MJ, Jacoby WB. Glutathione S-transferases: the first enzymatic step in mercapturic acid formation. J Biol Chem 1974;249:7130-9.

16. Gupta SP. Textbook of statistical methods. New Delhi: Sultan Chand and Sons Educational Publishers; 2014. p. 881-901.

17. Jadon A, Bhadauria M, Shukla S. Protective effect of Terminalia belerica Roxb. and gallic acid against $\mathrm{CCl}_{4}$ induced damage in albino rats. J Ethnopharmacol 2007;109:214-8.

18. Sathiavelu J, Senapathy GJ, Devaraj R. Hepatoprotective effect of chrysin on prooxidant-antioxidant status during ethanolinduced toxicity in female albino rats. J Pharm Pharmacol 2009;61:809-17.

19. Margaret JJ, Jayshree N. Phytochemical screening and in vitro hepatoprotective activity on the berries of Vitex agnus castus. Int J Pharm Industrial Res 2014;4:28-32.

20. Lizby A, Mathews D, Dhanyaraj P, Prathibhakumari V, G Prasad. Hepatoprotective and antioxidant potential of Sphaeranthus 
indicus [linn] on liver damage in wistar rats. Int J Pharm Pharm Sci 2012;4:222-5.

21. Hussain K, Scott BR, Reddy SK, Somani S. Chronic ethanol and nicotine interaction on rat tissue antioxidant defense system. Alcohol 2001;25:89-97.

22. Molina P, Mclain C, Villa D. Molecular pathology and clinical aspects of alcohol-induced tissue injury. Alcoholism: Clin Exp Res 2002;26:120-8.
23. Ji X, Zhang $\mathrm{P}$, Armstrong RN, Gilliland GL. The three dimensional structure of a glutathione-s-transferase from the $\mathrm{Mu}$ gene class. Structural analysis of the binary complex of isoenzymes 3-3 and glutathione at 2.2-A resolution. Biochemistry 1992;31:10169-84.

24. Ighodaro OM, Omole JO. Ethanol-induced hepatotoxicity in male wistar rats: Effects of aqueous leaf extract of Ocimum gratissimum. J Med Med Sci 2012;3:499-505. 